\title{
Disentangling Religion and Culture: Americanizing Islam as the Price of Assimilation
}

\author{
JOHN H. MORGAN 1
}

\begin{abstract}
This essay is an exploration into the social inevitabilities of culture shifts within the American Muslim community's self-understanding of their faith. Rather than a theological explication of the reasons why and why not Islam may or can or will not assimilate in America, our approach will be strictly sociological thereby side-stepping the intricate dialectic of theological niceties in deference to the social realities of culture change. As a social psychologist, my duty is to acknowledge the inevitabilities of behavioral shifts brought about due to social and cultural pressures resulting from immigration into an alien cultural weltanschauung, i.e., worldview. Therefore in this essay, we will explicate the meaning and nature of de-ethnicization and reenculturation as we endeavor to disentangle religion from culture, recognizing that much of what goes under the flag of religious orthodoxy is really culturally-mandated behavior and worldview. The assimilation process, however, will bear heavily upon the necessity for Muslim clergy in America to become professional by Western standards and we will in the process explore the complexities of religious secularism as a way of becoming an "American" Muslim. Finally, we will suggest liturgical and architectural "adjustments" to Western modes of public worship while indicating linguistic niceties which will prove helpful in the assimilation process which we have chosen here to call the "Islamicization of America".
\end{abstract}

Keywords: Americanization, assimilation, culture change, de-ethnicization, Islam, Muslim, re-enculturation

Certainly our generation is faced with one of the great historical challenges of human migration, namely, the sorting out of those components of culture and religion which are indispensable and those which are, lamentably but necessarily, disposable (Morgan 2006a). Not just theologians and politicians are involved in this culling out of what must be kept and what may, alas, be let go. The immigrant families themselves directly feel the impact when moving from home to an alien culture which celebrates another religion. Yet and still, this happens, it must happen, it cannot be stopped from happening. The de-ethnicization process is inevitably linked to cross-cultural immigration (Morgan 2010). America is the great testing ground for this phenomenon, not that it has not and does not and will not occur elsewhere but in America the process constitutes a domain assumption in "becoming an American" (Bowman \& Haleem 1999: 23).

The ease with which, for the most part, Italians and Irish and Germans and Poles made the transition from being predominantly Italian, Irish, German, and Polish to being conspicuously American was greatly facilitated by the fact that they were all, more or less, already immersed in the religion of America, namely, Christianity (and predominantly Catholic Christianity) (Howe

${ }^{1}$ John H. Morgan, Ph.D., D.Sc., Psy.D., Karl Mannheim Professor of the History and Philosophy of the Social Sciences at the Graduate Theological Foundation, Dodge House, 415 Lincoln Way East, Mishawaka, 46544 INDIANA, United States of America, Email: faculty@gtfeduction.org. 
1989: 48). Relinquishing the language, the dress, and somewhat the cuisine was eased by not giving up their long-held faith with a worldview that provided a sound medium through which to interpret this New World encountered during immigrant. For immigrant Jews of the $19^{\text {th }}$ century, the transition was not so easy but in addition to divesting themselves of the visible trappings of Eastern European Jewish culture, such as styles of dress and speech. However, they were not able or, indeed, willing to give up their ethnic identify as Jews and certainly not their Jewish religion which inevitably and understandably exacerbated the transition to American culture (Morgan 2010a). Certainly, adjustments were made so that though Yiddish was reluctantly but necessarily relinquished, so that the learning of English became the great push with the 19th century Jewish communities in America. The divestiture of the more conspicuously visible dress styles of Eastern European village and peasant life (with the exception of wearing the yarmulka) folowed quickly as well. The cuisine is usually the last of the cultural trappings to undergo either a banishment or a modification for food is consumed within the confines of the immigrant's home and does not draw secular attention the way clothing styles and worship do. The emergence of Reform Judaism in America is the classic demonstration of the de-ethnicization and re-enculturation process and the life and work of Rabbi Isaac M. Wise constitutes the sine quo non of the embodiment of this process (Heller 1965). Elsewhere, this author has explored in some detail lessons which might be learned by Muslim religious leaders from this Reform rabbi (Morgan 2010a).

When we come to $21^{\text {st }}$ century American immigrant Muslims, we encounter a similar challenge of assimilation where religion and culture are forced to disentangle themselves (AlQaradawi 1999). Unlike the United Kingdom and Western European countries, America has enjoyed the influx of a middle-class professional movement of educated Muslims from the Middle East, Indonesian, and India as the predominant immigrant profile. Whereas the UK and other European Union countries have, owing to their different histories of relationship to Muslim countries, a disproportionate percentage of poor, unskilled and working-class Muslims, America has enjoyed the coming of the highest echelon of the Muslim immigrant community (Haddad 1993). This socioeconomic reality has placed the American Muslim community in a uniquely advantageous position of fostering a responsible and creative integration of Western culture with immigrant culture and has introduced the possibility of an ideological adjustment to the faith of Islam to accommodate but not diminish either their cultural heritage or their religious commitment (Nyang 1999).

The disentangling of religion (transcendent reality) and culture (temporal reality) sprovide a hermeneutical tool for sorting through the plethora of ingredients found in both religion and culture and will, if carefully defined, assist the sorting-out process of what to keep and what must be relinquished. Let us then, for purposes of this discussion, employ the following definitions as operative tools for excavation. "Religion" is; (1) a complex of behaviors and ideologies, (2) consisting of rituals and myths, (3) which appeals to a transcendent legitimacy, (4) embodying a worldview and ethos, (5) addressing the verities of life and existence, and (6) conveying a dynamic level of psycho/social reality, (7) which is self-validating to the individual and community. On the other hand, "culture" is; (1) a complex of behaviors and ideologies, (2) consisting of rituals and myths, (3) which appeals to an historico-temporal legitimacy, (4) embodying a worldview and ethos, (5) addressing the verities of life and existence, and (6) conveying a dynamic level of psycho/social reality, (7) which is self-validating to the individual and community (Morgan 2007: 26 \& 39). These two terms as defined here provide us with a mechanism to assist the immigrant Muslim community in determining what must be disentangled - what is "religious" about the practice of the faith of Islam and what is "cultural" about the practice of the faith of Islam (Morgan 2010a). By identifying the root and core of the Muslim faith and by recognizing those elements in the practice of that faith which are rather cultural than theological, i.e., those things are that historical and temporal in the practice and those things are that understood by the faithful to be transcendently indispensable to the practice of the faith, a way can be chartered for the assimilation 
into another culture without jeopardizing either the core of the faith or that which is indispensably cherished in the culture (Khan 1999).

\section{Muslim Clergy and Professionalization: Educational Leadership in Transformation}

As was true with the immigrant rabbis of the $19^{\text {th }}$ century in America, the transition from a traditional culture to a secularized western society such as America was then and is now prove to be a great challenge to the rabbis who had had their rabbinic training prior to their arrival in New York (Knobel \& Staitman 2000). To have been trained as a rabbi in Poland or Austria or Germany within the historic ghettoes by Yiddish and Hebrew speaking teachers of great learning but a narrowly defined concept of rabbinic practice did not serve well the young rabbi immigrant to America where the concept of a "professional clergy person" was profoundly different and expansive. The challenge confronted by any ethno-religious immigration community is most often felt acutely by their religious leaders (Goren 1970). The Jewish community's rabbis were overwhelmed with the disparity of their skills learned in the old countries and the demands of their immigrant communities in this country. Immigrant Jews inevitably took on the expectations of their Christian counterparts (Fernea 1998). Suffice it to say that leading the Saturday prayers and teaching the Talmud during the week to youngsters was a far cry from what the wider Christian community expected of their clergy, Protestant or Catholic (Madison 1976). These clergy were expected to be highly educated in western learning, speaking, and writing. It was generally assumed that they were the embodiment of a classical education offering, not just scholarly sermons, but leading in sophisticatedly and elaborate liturgy as well. As with their Christian counterparts in the priesthood, these immigrant rabbis were likewise expected to function as counselors, skilled and trained in pastoral care, to families and individuals within the faith community.

Needless to say, Eastern European trained rabbis had much to learn and so it is with the Middle Eastern and Indian imams coming to this country. Their depth of knowledge of the Qur'an and the Hadiths of the Prophet and a well-developed pronunciation of the Arabic prayers in the Friday liturgy but little else in terms of training will not satisfy the rising expectations of the Westernized Muslim (Morgan 2012a). One of the striking deficits of the immigrant clergy Christian, Jewish, or Muslim - was a strong foreign accent which was decidedly off-putting both to secular society as well as their own faith communities where English was spoken well and accent free by the young. Cruel and unfair as it blatantly is, the fact that a Muslim religious leader speaking with a strong foreign accent inevitably and regrettably raises the fears of those who know nothing of Islam expect the warped image portrayed by the popular media. The Muslim community does not do itself a favor by continuing to fail to cultivate its own young American born and reared imams to assume leadership of their communities (Morgan 2012 a).

Furthermore and in order for the Americanization process to occur to the advantage of the Muslim community, it is going to be imperative that, first, immigrant imams learn quickly what is understood in America to mean "professional" clergy, and second, it is going to be imperative that the American Muslim community, like the Jews before them, establish a sound academically respected school of theology for the training of American imams for the American Muslim community (Morgan 2012). It should be mentioned here that for the establishment of the Muslim community's rightful place in American society to be assured, the elevation of the imam in the broader secular community by education as well as by liturgical endorsement will prove most valuable. Any immigrant ethno-religious community will do itself no favors by insisting upon ignoring the expectations of the broader secular society within which it finds itself seeking acceptance. The absence of any liturgical semblance of an "ordination" or "formalized installation" of the imam as the designated religious leadership of the masjid is a great deterrent to the rightful acknowledgement of the wider secular society in which they are intended to serve. It should be 
stated here unequivocally that there is nothing in the teachings of Islam which preclude the formalizing, for purposes of satisfying the outside world, the installation of the imam as religious leader of the masjid. Importing imams from the Middle East is, at best, a stop gap measure unworthy of a strong, professionally and financially sound immigrant community (Morgan 2010b). An American institution must be established to train young American Muslims to be American imams. Nothing short of this will do in the assimilation process. The Jews very quickly established both the Hebrew Union College of Cincinnati and the Jewish Theological Seminary of New York for the training of American rabbis and the Catholic Church immediately began to establish seminaries within each of the diocesan judicatories for the purpose of producing American-educated priests. American Muslims must not ignore the significance of this historical fact if that community intends to be established and recognized as distinctively American in its life and work (Osborne 1988; Heller 1965; Morgan 2010a).

\section{Religious Secularism as Social Assimilation: Becoming an “American” Muslim}

Religious secularism is a baffling concept though readily recognized and studied within the behavioral and social sciences. The use of the term and concept has grown out of the realization that a large percentage of Americans identify themselves as "spiritual" but decidedly not "religious" (Morgan 2006b). This distinction, initially rather trivial and ill-defined, has taken on a level of sophistication in recent years owing to the reality that the number of Americans embracing a sense of their own self-defined "spirituality" while rather outspokenly disavowing any allegiance to institutionally organized religion is, in fact, a numerically substantial reality. Furthermore, this notion of being spiritual without the benefit of church or clergy reaches across religious traditions and cultural boundaries (Morgan 2006c). Popular culture expressed and embodied in the media, film, music, art, and consumerism generally has adopted the term and concept and now regularly we find nationally reputable members of each of these expressive communities speaking of their spirituality but publicly abjuring religious institutional affiliation. To be an American means increasingly to be spiritually self-aware while distancing oneself from religious institutions. This is a phenomenon equally present within Judaism, Christianity, and Islam. Among Muslim youth, according to Omar Shahin, Executive Director of the North American Imams Federation, this phenomenon is growing leaps and bounds, matching in many respects what has happened in the Jewish, Christian, Hindu and Buddhist communities in America as well (Shahin 2007). Being an American Muslim does not any longer necessarily imply involvement in the Friday prayers or religious life of the masjid. Possibly and commonly, being attached to the faith community by virtue of merely casual uses of certain religio-cultural expressions, symbols, sensibilities, and ideological indicators is becoming the normative behavior of $2^{\text {nd }}$ and $3^{\text {rd }}$ generation Muslims in America. Assimilation implies being alike, looking alike, and doing alike and the youth culture across the religious and ethnic spectrum in America has chosen religious secularism over institutional allegiances to the understandable lament of the older generation of immigrants.

\section{Liturgical and Architectural Westernization: The English Language, Chairs, and Benches}

Whether it is legitimate for a behavioral scientist to excuse himself from being theologically informed is left to the reader to decide. Nevertheless, and even at the risk of committing a theological blunder, I venture to propose certain liturgical and architectural adjustments within the practice of Islam in America based on my knowledge of what both the Christian and Jewish immigrants have chosen to do over the past two centuries, and I might way, with great success (Dolan 1985). Rabbi Isaac M. Wise, whom some consider the father of Reform Judaism in America, was flabbergasted at the archaic and retrograde liturgical and architectural insensitivity to the 
demands of a Westernized American Judaica when, upon arrival from eastern Europe, he found the synagogues and temples not unlike the old country in both liturgy and their houses of worship (Heller 1965). "Where are the American Jews?" he lamented upon arrival in New York in the mid1800s. He called for a gradual but effective transformation of Jewish worship from the old country to the new, responding to the more secularized and socio-cultural expectations of American society. Islam in America must do the same thing if it is, as with Judaism and Christianity, to become as common as apple pie. The Americanization of Islam is the price of assimilation and assimilation is the price for doing business in America as a fully-recognized and accepted member of the community. There is nothing implicit in the faith of Muslims to preclude them becoming an integral part of the American cultural fabric any more than there was among the immigrant Irish Catholics or Italians or Germans or, for that matter, the European Jews. But the price of assimilation is the price of enculturation and integration.

Illustrative of this rather obvious point has to do with the use of the English language, chairs, and benches. Be it far from this author to impinge upon the sacredness of the Arabic language and its central place in the practice of Islam. That being said, one does not have to be a Qur'anic scholar to know that the Friday worship need not be solely and exclusively in Arabic for it is not so prescribed in the Hadiths of the Prophet (Al-Qaradawi 1999). There are portions which must be said in Arabic and the imams are fully aware of that but those portions which are not may and should be said in the language of the culture in which Muslim worship is occurring. Why not? If and when (and let it be soon) the imams serving in the masjids of America are born, raised, and trained in America as imams begin to lead the Friday worship, why not and should not they be said in English. And that spoken English will and should be without a foreign accent, a thing which is often troubling to the visitor enquiring of Islam (Bowman \& Haleem 1999).

And why, in a Western society like America, must every male be expected to sit on bended knees on the floor of the house of worship? Granted, allowances are made (sometimes and somewhat reluctantly) for the aged, infirm, and stiff of joints by providing them with a chair but the conspicuous display of such an exception often results in that individual opting not to attend the worship at all. And, if exceptions are allowed owing to health and age, why not allow everyone the exception for, in America, we sit in chairs or on benches when worshipping in the synagogue and in the church building? English prayers and sermons listened to and participated in while sitting on benches is an American given and there is nothing in Islam to forbid this universal practice. In the medieval cathedrals of Europe the peasants were expected to stand throughout the entire worship service but when the Pilgrim Fathers came to this country there was no question but that everyone, rich and poor, male and female, adult and child, would have a bench upon which to sit for prayers and worship. One must not assume that the mystery and majesty of Islamic worship would be in any way diminished by such western adjustments. The attraction and accessibility of that worship would be greatly enhanced for the western enquirer and visitor unaccustomed to sitting on the floor on bended knees.

One more little concern has to do with the requirement that worshippers must do so barefooted, or at least in the absence of shoes. This is, of course, not a Qur'anic directive but one which understandably derives from ethno-cultural concerns about cleanliness (Al-Qaradawi 1999; Doi 1984). The washing of the body before prayers is a similar point of consideration but for our purposes, the Westernized masjid community might consider doing what Christians and Jews did hundreds of years ago, namely, dispense with the barefoot requirement in deference to the realization that in America such a cultural legacy is out of place in a society that emphasizes personal cleanliness. The exposure of the shoeless foot is more offensive than the possible dusty floor of the house of worship. Jesus washed his disciples feet because they were dirty and the act symbolized humility. In $21^{\text {st }}$ century America, dirty feet are unacceptable whether at the mall or in the house of worship. 
Furthermore and in conclusion, this simple furniture adjustment would make it much more conducive for women and men sitting together in worship with their families (Fernea 1998). The old tired argument that there would be an inappropriate exposure of women's bodies during prayer if men and women worshipped together would be summarily dismissed by getting up off the floor and sitting respectfully and submissively on benches or chairs. No one in Western society would ever presume that sitting in a chair or on a bench precluded either respect or humility. And, an added advantage would be that whole families could sit and worship together (Shahin 2007). The Jews faced this dilemma when they came from 19th Eastern Europe and with the introduction of benches and common gender family worship, Judaism was transformed in this country from the domain of the old men sitting in the synagogue to that of a family faith experience. The results has been remarkably positive for Judaism and the prognosis would be likewise for Islam (Stowasser 1994). Religious secularism and spirituality without religion would be more likely challenged with families worshipping together as a family at Friday prayers. It is not without saying that the American expression - "The family that prayers together, stays together" - has merit in this particular situation.

\section{Linguistic and Nomenclatural Niceties in Erosion: Say "Hello," not "as-Salaamu”}

Must one say "as-salamu alaykum" to a brother or sister Muslim in order to be a good Muslim? Or to be faithful to Islam? Or, might it rather function linguistically (and possibly subconsciously) to separate a Muslim from a non-Muslim? Might it be somewhat even exclusivistic to do so? The Arabic expression is beautiful and bespeaks an allegiance to Islam by virtue of being spoken in Arabic, but most Muslims in the world are not Arab and do not speak Arabic as their nature tongue (Haddad 1993). In spite of its elegant beauty, the Arabic language is not and will not become a universal language. Excepting for special religious and familial occasions, the Jews have ceased the use of "shalom" as the fundamental greeting between Jews in America. Is there a cultural distancing from non-Muslims which results from the use of that greeting rather than an English expression of greeting such as "Hello"? I have been scolded for not understanding that within the African American Muslim community, personal names which are very Arabic sounding are crucial to the new identify a convert feels to Islam by taking such names. I failed but have been duely corrected in understanding the emotional attachment resulting from the name change particularly among African American Muslims. I am willing to concede that argument. However, is it necessary for all American Muslims to elevate the Arabic-sounding names of their children in order to secure their allegiance to Islam? Granted, the Irish prefer Patrick and the prefixes to their surnames are inevitable indicators of their Irish heritage (Doi 1984; Goren 1970). However, the surnames of most Muslim immigrants are not Arabic but India or Indonesian or Eastern European and the adoption of the name of the Prophet as a part of an American Muslim child's name seems only right and proper. However, the continual utilization of Arabic-sounding first names seems to suggest, rightly or wrongly, that there is an eagerness to somehow distance oneself from American culture. To the extent that religio-cultural names have become or are imbedded in American culture itself, such as Patrick or David owing to Christian history or the Jewish Bible, these will continue. Whether the same will be said of Arabic names, only time will tell. In the meantime, young Muslim families may ponder the advantages of assimilation for their children in the choosing of a name which fosters familiarity within American culture (Morgan 2010). 


\section{Islamicization of America as an Inevitability: Everyone Knows a Muslim}

In this assimilation process, quite clearly Islam is being Americanized (Nyang 1999). For good or ill, only time will tell, but that it is happening is indisputable. The price being paid by Islam is the price of assimilation and assimilation is the price, as we have been saying, for doing business in America. How to hold on to what counts, what is valuable, what is central and meaningful to the Muslim individual and the Muslim family is what we are exploring here (Shahin 2007). That some things will have to be given up in the de-ethnicization process and the re-enculturation of the immigrant Muslim community is without question true. The determination of what is indispensable and what, inevitably, must be given up is the challenge being confronted by the Muslim community and its leaders (Morgan 2010a). But, lest we forget our own immediate history, not only is Islam becoming more American but America is becoming more Muslim! (Bowman \& Haleem 1999). This is a reality which cannot be denied, what must be recognized, lauded, and embraced. The integration of the Irish Catholics and the Eastern European Jews has changed the face of this continent forever and for the better (Howe 1989; White 1989). The integration of Muslims from all over the world into American society will prove likewise to our mutual benefit. Striking a balance between the Americanization of Islam and the Islamicization of America will prove a great asset to our future as a people and a nation.

The Americanizing of Islam is an inevitability. It is going to happen. It is happening right now. The Muslim community and its clergy are confronting a situation of immediacy and urgency. The Islamicization of America will happen but must follow, not lead, the Americanization process. It can even be argued, albeit ironically, that terrorists did American Muslims a major favor, though unintentionally, when they elevated the American Muslim community to a national agenda. Before 9/11, Muslims in America were by and large left to themselves, working as physicians, engineers, attorneys, teachers, and professionals of all kinds. They went about their daily lives without much bother or concern, and, unfortunately, without a deeply instilled sense of attachment to other Muslims and other Muslim communities. We realize that 9/ll changed all of that, not unlike what Wounded Knee did for the Native Americans who, prior to that event and the rise of the American Indian Movement, normally just thought of themselves in terms of their own tribal attachments.

The Americanization of Islam has to do with acculturation and assimilation. Realizing the gradations of "adopting versus adapting," of modifying and blending versus "drifting" in cultural attrition, is American Muslim's most important challenge of discernment. An immigrant culture struggling to hang onto its own traditionalist identity may find that adopting some new ways is simply not possible and so will, therefore, find themselves fighting change at every point. The assimilationists will find that, even though adopting new cultural modes may not be easy or convenient, they will find that "adapting" new cultural modes of being in the new environment will serve them in good stead. Adapting calls for creative integration of the old ways with the new, the way "things were always done" to the way "things as they are to be." Youth in dialogue with the elderly constitutes the matrix for such meaningful and viable "adaptation" (Shahin 2007; Stowasser 1994). Imams engaged in the process of assimilation will be wise to facilitate these interactions and these discussions between old and young, as difficult as that may on occasion be for both groups involved.

This process need not degenerate into a cultural drift away from the fundamental structures of the community if responsible leadership is exercised. Conflicts and concessions may be modulated by empowering the old and the new, the young and the elderly of the community, in this work of creatively responsible assimilation. To raise up and perpetuate a sold middle-class generation of American Muslims is the goal and the convergence of the Americanization of Islam with the Islamicization of America is crucial if Islam is to find itself happily at home in America. 


\section{References}

Bowman, Betty \& Haleem, Muzallar. 1999. The Sun is Rising in the West. Beltsville: Amana Publications.

Doi, Abdur Rahman I. 1984. Shari'ah: The Islamic Law. London: Ta Ha Publishers.

Dolan, Jay. 1985. The American Catholic Experience: A History from Colonial Times to the Present. Garden City, New York: Doubleday.

Fernea, Elizabeth W. 1998. In Search of Islamic Feminism. New York: Doubleday.

al-Ghazali, Sheikh Muhammad. 1998. Journey Through the Qur'an. London: Dar Al-Taqwa.

Goren, Arthur A. 1970. New York Jews and the Quest for Community: The Kehillah Experiment, 19081922. NY : Columbia University Press.

Haddad, Yvonne Yazbeck (ed.). 1993. The Muslims of America. New York: Oxford University Press.

Heller, James G. 1965. Isaac M. Wise: His Life, Work and Thought. New York: The Union of American Hebrew Congregations.

Howe, Irving. 1989. World of Our Fathers: The Journey of the East Homeland Jews to America and the Life They Found and Made. New York: Schocken Books.

Khan, Maulana Wahiduddin. 1999. An Islamic Treasury of Virtues. New Delphi: Goodword Books.

Knobel, Peter S. \& Mark N. Staitman (Editors). 2000. An American Rabbinate: A Festschrift for Walter Jacob. Pittsburgh: Rodelf Shalom Press.

Madison, Charles A. 1976. Jewish Publishing in America: The Impact of Jewish Writing on American Culture. New York: Sanhedrin Press.

Morgan, John H. 2006. Being Human: Perspectives on Meaning and Interpretation (Essays in Religion, Culture and Personality). $2^{\text {nd }}$ edition. South Bend, Indiana: Cloverdale Books.

Morgan, John H. 2006a. Ideas and Behavior in Experiential Interaction: An Essay in Phenomenological Sociology. Ch. 4. In Morgan. Being Human: Perspectives on Meaning and Interpretation (Essays in Religion, Culture and Personality), pp. 69-92. $2^{\text {nd }}$ edition. South Bend, Indiana: Cloverdale Books.

Morgan, John H. 2006b. Meaning as Hermeneutics: the Deep Structure of Cultural Interpretation. Ch. 12. In Morgan. Being Human: Perspectives on Meaning and Interpretation (Essays in Religion, Culture and Personality), pp. 203-217. $2^{\text {nd }}$ edition. South Bend, Indiana: Cloverdale Books,

Morgan, John H. 2006c. In the Absence of God: Religious Humanism as Spiritual Journey. South Bend, Indiana: Cloverdale Books.

Morgan, John H. 2007. "In the Beginning...": Paleolithic Origins of Religious Consciousness. South Bend, Indiana: Cloverdale Books.

Morgan, John H. 2010. The Immigrant Imam and His Family in America. Islamic Horizon Magazine 39: \#6: $51 \mathrm{ff}$.

Morgan, John H. 2010a. Lessons from the American Rabbinic Experience: What Muslim Clergy Need to Know. Journal of Religion and Society XII(Summer): 1-14.

Morgan, John H. 2010b. Professionalization of Islamic Ministry in America: Components of the Legitimizing Process in Western Society. Journal of Religions and Ideologies 9(Summer): \#26: 1-14.

Morgan, John H. 2011. Beyond Ethical Theism: Morality as Service to God in Classical Islamic Philosophy. Contemporary Islamic Studies.

Morgan, John H. 2012. Islamic Clergy and the Professionalization of Their Ministry in America: Legitimizing the Process in Wstern Society. VI International Encounter of Socio-Religious Studies, The Havana Conference 2012.

Morgan, John H. 2012a. Muslim Clergy in America: Ministry as Profession in the Islamic Community. Expanded 2nd edition. Lima, Ohio: Wyndham Hall Press. 
Nyang, Sulayman S. 1999. Islam in the United States of America. Chicago: ABC International Group, Inc.

Osborne, OFM, Kenan B. 1988. Priesthood: A History of the Ordained Ministry in the Roman Catholic Church. NY : Paulist Press.

al-Qaradawi, Yusuf. 1999. The Lawful and Prohibited in Islam. Indianapolis: American Trust Publications.

Shahin, Omar. 2007. The Muslim Family in Western Society: A Study in Islamic Law. South Bend, Indiana: Cloverdale Books.

Stowasser, Barbara Freyer. n.d. Women in the Qur'an, traditions, and Interpretation. New York: Oxford University Press.

White, Joseph M. 1989. The Diocesan Seminary in the United States: A History from the 1780s to the Present. South Bend, Indiana: University of Notre Dame Press. 